\title{
THE IDENTITY AND TYPIFICATION OF \\ VALLIERA TRIPLINERVIS (SALICACEAE)
}

\author{
Laurence J. Dorr \\ Department of Botany \\ National Museum of Natural History, MRC-166 \\ Smithsonian Institution, P.O. Box 37012 \\ Washington, D.C. 20013-7012, U.S.A. \\ dorr@si.edu
}

\author{
Mac H. Alford \\ Department of Biological Sciences \\ The University of Southern Mississippi \\ 118 College Drive, Box 5018 \\ Hattiesburg, Mississippi 39406, U.S.A. \\ mac.alford@usm.edu
}

ABSTRACT

The genus Valliera is reduced to synonymy under Neosprucea. Its sole species, V. triplinervis, is considered to be conspecific with N. grandiflora. A lectotype is designated for the former species name.

KeY WoRds: Neosprucea, Salicaceae, South America, Valliera

RESUMEN

El género Valliera se reduce a sinonimia bajo Neosprucea. Su única especie, V. triplinervis, se considera conespecífica con N. grandifolia. Se designa un lectotipo para el nombre de la especie anterior.

Palabras Claves: Neosprucea, Salicaceae, South America, Valliera

The monotypic genus Valliera Ruiz \& Pav. was published posthumously in the fifth volume of the Flora Peruviana, et Chilensis (Ruiz \& Pavon 1958, 1959), the original 19th century manuscript resurrected by Alvarez López who also provided brief introductory notes. The authors of the generic name were not explicit about its family placement; they included it in "Polyandria Monogynia" and inserted it between descriptions of species of Marcgraviaceae and Muntingiaceae. Original material (MA [MA815601], see JSTOR-Plants 2018; P [P06822531], see MNHN 2018) is annotated "Muntingia accedens," which indicates that Ruiz and Pavon recognized a similarity to Muntingia L. (Muntingiaceae).

Valliera was assigned to Tiliaceae in Index Kewensis (Taylor 1966), and this is where it is placed in several other indices (Farr et al. 1979; IPNI 2018). Its placement in Malvaceae (Tropicos 2018) apparently is based on the acceptance of a broader circumscription of Malvaceae that includes Tiliaceae (e.g., Angiosperm Phylogeny Group 2016). Airy Shaw in Willis $(1966,1973)$ was less certain about where the genus belonged and wrote "Tiliaceae? Flacourtiaceae?" Hinsley (2018), without explanation, included Valliera as a syononym of Pterospermum Schreb. (Malvaceae), which is improbable given that Pterospermum is an Old World genus, not a South American one, and the floral characters of the two genera are fundamentally different (e.g., 5- versus 1-carpellate ovary, etc.). Johansson (2018) considered Valliera a nomen dubium. Similarly, the Plant List (2018) regarded the name of the sole species, V. triplinervis Ruiz \& Pav., to be unresolved.

\section{Identity of Valliera}

Examination of the protologue and images of original material in Madrid (JSTOR-Plants 2018, sub Valliera) and Paris (MNHN 2018, sub Neosprucea grandiflora), as well as a color illustration by expedition artist Xavier Cortés y Alcoser (JSTOR-Plants 2018, sub Valliera; Tafalla 1989b, t. 57) convinces us that Valliera is a synonym of Neosprucea Sleumer (Salicaceae). A number of genera in Salicaceae (or former Flacourtiaceae sensu Lemke 1988), including Neosprucea, are easily accommodated in the Linnaean "Polyandria Monogynia." Valliera, like Neosprucea, has large, showy flowers, poricidal anther dehiscence, parietal placentation, and acrodromous leaf venation more or less reminiscent of Melastomataceae. In addition, both genera have 4-5 sepals; 4-5 petals; numerous stamens dehiscent by oblique extrorse pores at the apex; and a gynoecium comprised of a single, superior spherical to ovoid ovary with a simple style. Several species of Neosprucea also have the filamentous staminodes and creamy-white to white corolla of Valliera. 
Alford (2008) recognized nine species of Neosprucea in his revision of the genus. Valliera triplinervis best matches N. grandiflora (Spruce ex Benth.) Sleumer. Both have coarsely toothed, elliptic, adaxially glabrous leaves, creamy-white to white corolla with narrowly ovate to lanceolate petals, numerous staminodes, and long filaments relative to the anthers. The illustration of $V$. triplinervis accompanying the original description depicts a glabrous anther (Ruiz \& Pavon 1958, t. 438 a3), which is discordant with the hirsute anthers of $N$. grandiflora (see Alford 2008, fig. 8 G). Nonetheless, the leaf venation, staminodes, and lack of pronounced petiolar pulvini of V. triplinervis match $N$. grandiflora and do not match the two species, N. montana Cuatrec. and N. sararensis Cuatrec., that have glabrous anthers, pronounced petiolar pulvini, and lack staminodes. Likewise, the flowers of V. triplinervis are identical to those of the type of Banara grandiflora Spruce ex Benth. ( $\equiv N$. grandiflora). We can only assume that Xavier Cortés y Alcoser overlooked the hairs on the anthers of V. triplinervis when he prepared his plate.

\section{Nomenclature}

Neosprucea Sleumer, Notizbl. Bot. Gart. Berlin-Dahlem 14:47. 1938. Spruceanthus Sleumer, Notizbl. Bot. Gart. Berlin-Dahlem 13:362. 1936, non Spruceanthus Verd., Ann. Bryol., Suppl. 4:151. 1934. Type: Neosprucea grandiflora (Spruce ex Benth.) Sleumer.

Valliera Ruiz \& Pav., Anales Inst. Bot. A.J. Cavanilles 16:397. 1958 [1959], syn. nov. TyPE: Valliera triplinervis Ruiz \& Pav.

Neosprucea grandiflora (Spruce ex Benth.) Sleumer, Notizbl. Bot. Gart. Berlin-Dahlem 14:47. 1938. Banara grandiflora Spruce ex Benth., J. Proc. Linn. Soc., Bot. 5(Suppl. 2):93. 1861. Hasseltia grandiflora (Spruce ex Benth.) Sleumer, Notizbl. Bot. Gart. Berlin-Dahlem 11:960. 1933 [1934]. Spruceanthus grandiflorus (Spruce ex Benth.) Sleumer, Notizbl. Bot. Gart. Berlin-Dahlem 13:363. 1936. Type: Peru. Prope Tarapoto, 1855-6, Spruce 4897 (holotype: K [K000591627]; Isotypes: B [B 10 0243741], BM [BM000616674], BR [BR0000006411268], E [E00296683], F [F0041328F], G [G00364307]!, GH [GH00066409], GOET [GOET003826], K [K000591628]!, KW [image], LD [LDl420080], NY [NY00097838], P [P02428321]!, TCD [TCD0005441], W [W-Rchb. 1889-0158703]!).

Neosprucea sucumbiensis Cuatrec., Trop. Woods 101:23. 1955. Type: Colombia. Putumayo: Río San Miquel en el afluente izquierda Quebrada de la Hormiga, 12 Dec 1940, Cuatrecasas 11147 (ноLотYPE: US [US00114692]!; ISOTYPEs: COL [COL000002935]!, L [L0011149]!).

Valliera triplinervis Ruiz \& Pav., Anales Inst. Bot. A.J. Cavanilles 16:399, t. 438, fig. a. 1958 [1959], syn. nov. TyPE: ECUAdor. "in Pozuelo, ad margines fluminis Provinciae Huayaquil," 1800, Ruiz \& Pavón s.n. (LECtotype, here designated: MA [MA815601]; possible ISOLECTOTYPE: P [P06822531]).

We attribute the lectotype collection to H. Ruiz and J. Pavon even though evidence indicates that J. Tafalla Navascués collected the specimen. It is included as "Genus Novum Muntingie accd. Trinerva" in Tafalla’s Flora Huayaquilensis (Tafalla 1989a, p. 104; 1989b, t. 57), yet another posthumous publication emanating from the expedition of Ruiz and Pavon.

\section{ACKNOWLEDGMENT}

Two anonymous reviewers made helpful suggestions for improving the manuscript.

\section{REFERENCES}

ALFORD, M.H. 2008. Revision of Neosprucea (Salicaceae). Syst. Bot. Monogr. 85:1-62. www.jstor.org/stable/25027975.

Anglosperm Phylogeny Group. 2016. An update of the Angiosperm Phylogeny Group classification for the orders and families of flowering plants: APG IV. Bot. J. Linn. Soc. 181:1-20. doi:10.1111/boj.12385.

FarR, E.R., J.A. Leussink, \& F.A. Stafleu, eds. 1979. Index nominum genericorum (plantarum). Vol. 3. Bohn, Scheltema \& Holkema, Utrecht.

HinselY, S.R. 2018. Partial synonymy of Pterospermum. www.malvaceae.info/Synonymy/Synonymy.php?genus= Pterospermum. Accessed 16 Jan 2018.

IPNI. 2018. International plant names index. www.ipni.org. Accessed 16 Jan 2018.

JOHANSSON, J.T. 2018. The phylogeny of angiosperms. http://angio.bergianska.se/. Accessed 16 Jan 2018.

JSTOR-PLANTS. 2018. JSTOR global plants. http://plants.jstor.org/. Accessed 16 Jan 2018.

LEMKE, D.E. 1988. A synopsis of Flacourtiaceae. Aliso 12:29-43. 
MNHN. 2018. Muséum national d'Histoire naturelle, Paris (France). Collection: Vascular plants (P). http://coldb.mnhn.fr/ catalognumber/mnhn/p/p06822531. Accessed 16 Jan 2018.

PLANT List. 2018. The Plant List: A working list of all plant species. www.theplantlist.org. Accessed 16 Jan 2018.

Ruiz, H. \& J. PAvon. 1958 [1959]. Flora Peruviana, et Chilensis, sive descriptiones et icones, plantarum Peruvianarum, et Chilensium, secundeum systema Linnaeanum digestae, cum characteribus plurium generum evulgatorum reformatis, tomus V. Anales Inst. Bot. Cavanilles 16:353-462.

Ruiz, H. \& J. PAvon. 1959 [1960]. Flora Peruviana, et Chilensis, sive descriptiones et icones, plantarum Peruvianarum, et Chilensium, secundeum systema Linnaeanum digestae, cum characteribus plurium generum evulgatorum reformatis, tomus V (pars II). Anales Inst. Bot. Cavanilles 17:377-495.

TAfAlla, J. 1989a. Flora Huayaquilensis, vol. 1. Introductio historica et adnotaciones ab Eduardo Estrella confectae et descriptiones. Instituto ad Conservandam Naturam (ICONA, M.A.P.A.), Matriti [Madrid]. www.biodiversitylibrary.org/ item/144936.

TAfalla, J. 1989b. Flora Huayaquilensis, vol. 2. Icones. Instituto ad Conservandam Naturam (ICONA, M.A.P.A.), Matriti [Madrid]. www.biodiversitylibrary.org/item/144937.

TAYLOR, G. 1966. Index Kewensis plantarum phanerogamarum-Supplementum XIII. Clarendon Press, Oxford, U.K. wwW. biodiversitylibrary.org/item/134098.

Tropicos. 2018. Tropicos, botanical information system at the Missouri Botanical Garden. www.tropicos.org. Accessed 16 Jan 2018.

WILLIS, J.C. 1966. A dictionary of the flowering plants and ferns, ed. 7. University Press, Cambridge, U.K.

WILLIS, J.C. 1973. A dictionary of the flowering plants and ferns, ed. 8. University Press, Cambridge, U.K. 